\title{
SELECTED APPLICATIONS OF VIRTUAL REALITY IN MANUFACTURING
}

\author{
Jozef Novak-Marcincin* \\ Faculty of Manufacturing Technologies with a seat in Presov \\ Technical University of Kosice \\ Bayerova 1, 08001 Presov, Slovakia
}

\begin{abstract}
Virtual reality (VR) has become an important and useful tool in science and engineering. VR applications cover a wide range of industrial areas from product design to analysis, from product prototyping to manufacturing. The design and manufacturing of a product can be viewed, evaluated and improved in a virtual environment before its prototype is made, which is an enormous cost saving. Virtual Manufacturing (VM) is the use of computer models and simulations of manufacturing processes to aid in the design and production of manufactured products. VM is the use of manufacturing-based simulations to optimize the design of product and processes for a specific manufacturing goal such as: design for assembly; quality; lean operations; and/or flexibility.
\end{abstract}

Key words: virtual reality, applications of virtual reality, virtual manufacturing

\section{INTRODUCTION}

Virtual reality is a technology that encompasses a broad spectrum of ideas. It defines an umbrella under which many researchers and companies express their work. The phrase was originated by Jaron Lanier the founder of VPL Research one of the original companies selling virtual reality systems. The term was defined as "a computer generated, interactive, three-dimensional environment in which a person is immersed". There are three key points in this definition. First, this virtual environment is a computer generated three-dimensional scene which requires high performance computer graphics to provide an adequate level of realism. The second point is that the virtual world is interactive. A user requires real-time response from the system to be able to interact with it in an effective manner. The last point is that the user is immersed in this virtual environment.

${ }^{*}$ Corresponding author's email: jozef.marcincin@tuke.sk 
One of the identifying marks of a virtual reality system is the head mounted display worn by users. These displays block out the entire external world and present to the wearer a view that is under the complete control of the computer. The user is completely immersed in an artificial world and becomes divorced from the real environment. For this immersion to appear realistic the virtual reality system must accurately sense how the user is moving and determine what effect that will have on the scene being rendered in the head mounted display.

\section{VIRTUAL REALITY AND VIRTUAL MANUFACTURING}

The term virtual manufacturing first came into prominence in the early 1990s, in part as a result of the U.S. Department of Defence Virtual Manufacturing Initiative. Both the concept and the term have now gained wide international acceptance and have somewhat broadened in scope. For the first half of the 1990s, pioneering work in this field has been done by a handful of major organizations, mainly in the aerospace, earthmoving equipment, and automobile industries, plus a few specialized academic research groups. Recently, accelerating worldwide market interest has become evident, fuelled by price and performance improvements in the hardware and software technologies required and by increased awareness of the huge potential of virtual manufacturing. Virtual manufacturing can be considered one of the enabling technologies for the rapidly developing information technology infrastructure [1].

Virtual manufacturing is used loosely in a number of contexts. It refers broadly to the modelling of manufacturing systems and components with effective use of audiovisual and/or other sensory features to simulate or design alternatives for an actual manufacturing environment, mainly through effective use of computers. The motivation is to enhance our ability to predict potential problems and inefficiencies in product functionality and manufacturability before real manufacturing occurs.
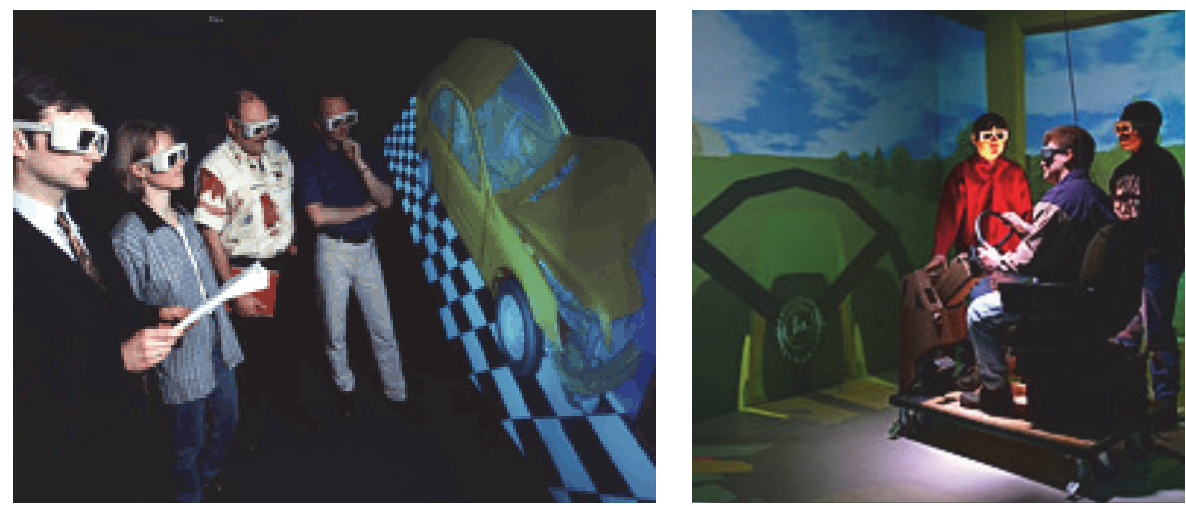

Figure 1 - Virtual manufacturing in automotive industry

Another term that is sometimes mentioned in the context of virtual manufacturing is agile manufacturing - sometimes defined as a structure within which agility is achieved through the integration of three primary resources: organization, people, and technologies. A way to achieve this is through innovative management structures and organization, a skill base of knowledgeable and empowered people, and flexible and intelligent technologies. Whereas agility focuses on the ability to make rapid changes in products and processes based on the voice of the customer, virtual 
manufacturing provides a means for doing so. Virtual reality (VR) has been used by companies such as General Motors and Caterpillar to build electronic prototypes of vehicles, instead of physical prototypes. This process reduces product development time significantly. Examples are on Figure 1.

\section{MAIN INFORMATION ABOUT VIRTUAL MANUFACTURING}

There are many definitions of Virtual Manufacturing (VM). Iwata in 1990 defines VM as follows: "A virtual manufacturing system is a computer system which can generate the same information about a manufacturing system's structure, states and behaviours as we can observe in real manufacturing systems".

The report from the 1994 Virtual Manufacturing User Workshop includes an in-depth analysis of VM and its definition: "Virtual Manufacturing is an integrated synthetic manufacturing environment exercised to enhance all levels of decision and control" was annotated extensively to cover all the current functional and business aspects of manufacturing. Also the practical side of manufacturing virtuality is highlighted in this useful analysis. A comprehensive and thorough survey of literature on VM problems relating to production design and control can be found in a study done at the University of Maryland.

The definition of VM given by a Bath University project team deserves attention. According to this definition: "Virtual Manufacturing is the use of a desk-top virtual reality system for the computer aided design of components and processes for manufacturing - for creating viewing three dimensional engineering models to be passed to numerically controlled machines for real manufacturing". This definition emphasizes the functions aiding the machining process.

It is unquestionable that virtual manufacturing aids real manufacturing processes and systems and it is perfected as the information technologies, the manufacturing systems and the business demands develop. In this context. Virtual Manufacturing should be recognized as an advanced information structure of Real Manufacturing Systems which integrates the available information tools and the virtual environment's immersiveness to achieve business manufacturing goals [2].

The combination of information technology (IT) and production technology has greatly changed traditional manufacturing industries. Many manufacturing tasks have been carried out as information processing within computers. For example, mechanical engineers can design and evaluate a new part in a 3D CAD system without constructing a real prototype. As many activities in manufacturing systems can be carried out using computer systems, the concept of virtual manufacturing (VM) has now evolved [3].

$\mathrm{VM}$ is defined as an integrated synthetic manufacturing environment for enhancing all levels of decision and control in a manufacturing system. VM is the integration of VR and manufacturing technologies. The scope of VM can range from an integration of the design sub-functions (such as drafting, finite element analysis and prototyping) to the complete functions within a manufacturing enterprise, such as planning, operations and control.

VM systems are integrated computer-based models that represent the precise structures of manufacturing systems and simulate their physical and informational behaviour in operation. VM technology has achieved much in reducing manufacturing cost and time-to-market, leading to an improvement in productivity. Much research effort to conceptualize and construct a VM system has been reported. Onosato and Iwata (1993) generated the concept of a VM system and Kimura (1993) described the product and process model of a VM system. Based on the concept and the model, a general modelling and simulation architecture for a VM system was developed by Iwata et al. (1995). Ebrahimi and Whalley (1998) developed a cutting force prediction model for 
simulating machining conditions in VM. A virtual machining laboratory for knowledge learning and skills training was implemented by Fang et al. (1998). In the virtual machining laboratory, both comprehensive knowledge learning and physical skills training can be achieved in an interactive synthetic environment. Using head-mounted stereo glasses and interactive gloves, students can virtually operate a lathe or set machining parameters and input CNC G-code program to cut the work-piece automatically, Machining process performance, such as machining conditions, cutting forces, cutting power, surface roughness and tool life, can also be simulated with the machining process evaluation models.

In addition, some commercial software for VM, such as Delmia's VNC, can simulate machining processes in a 3D environment and detect collision. By using a VM system, users can select and test different machining parameters to evaluate and optimize machining processes, and the manufacturing cost and time-to-market can be reduced, leading to an improvement in productivity. However, a practical VM system is highly multi-disciplinary in nature. Many of these research projects and commercial software for VM systems have restrictions in their implementation. Firstly, many machining theories and heuristics need to be modelled in a VM system. However, most VM applications are designed only for specific problems in pre-defined conditions. There is no one VM application having all the technologies necessary to model a real machining process. Secondly, each constructing process of a new VM system is akin to the reinvention of "wheels". Besides geometrical modelling of machines, analytical modelling of machining parameters, such as the cutting force, also has to be developed for every specific task. Lastly, various VM systems are developed with different programming and modelling languages, making them less flexible and scalable due to incompatibility problems. Any change $m$ one part would require the whole system to be modified.
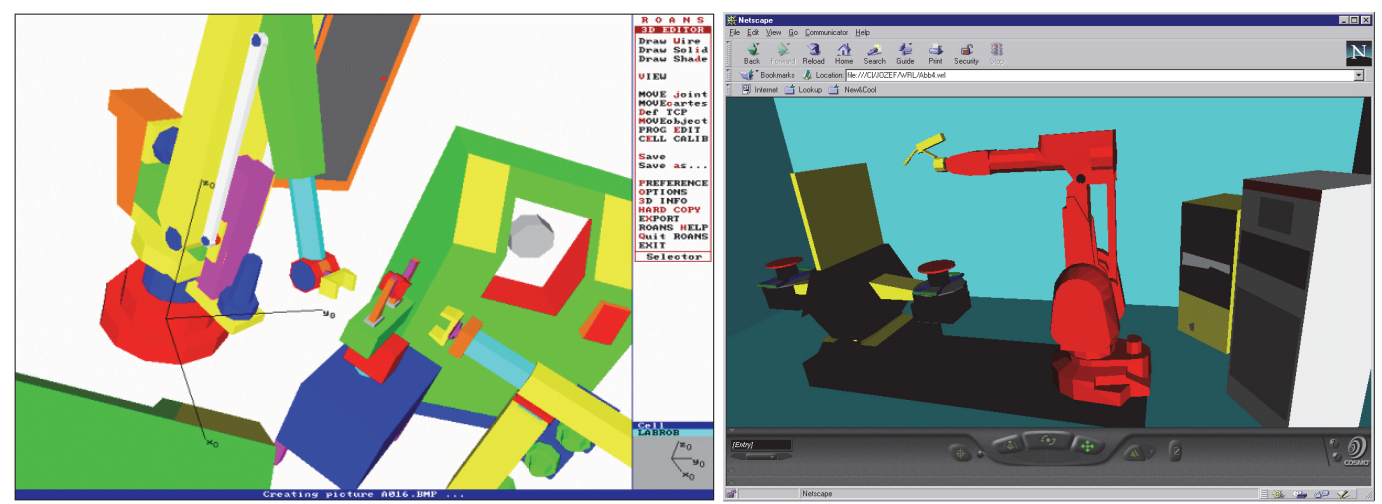

Figure 2 - Simulation of virtual workplaces activity

\section{APPLICATIONS OF VIRTUAL REALITY MODELING LANGUAGE IN MANUFACTURING}

VRML is description language, which belongs to a field Window on World System. Development of 3D graphic is connected with Silicon Graphic Corporation. This corporation creates expanded Open GL library. Under this library the format Open Inventor was proposed, which is the base for creating VRML 1.0. Official specification of VRML 1.0 was finished in 1995. In autumn 1995 
independent expert group - VRML Architecture Group (VAG) arised, which aim was coordination of other advance, to map user requirements for developing of new VRML format [4]. VRML 1.1 was only working proposal. The new format VRML 2.0 was approved in 1996 as ISO/IEC standard and became as international standard VRML 97. Format VRML 1.0 is the same format like Open Inventor, which is used by SGI. It is created for describing of static 3D scenes and enables connecting with URL. VRML 1.0 scene is presented by ASCII text file format. File VRML 1.0 has WRL suffix (world).

VRML 2.0 (VRML 97) is accurately new language, not only the expansion of VRML 1.0. Compared to the version VRML 1.0, it has lots of new abilities and simultaneously takes off or makes some properties from proceeding version easier. VRML 2.0 is the file format for describing interactive 3D scenes and objects. It can be used in collaboration with www and for 3D complex representations and creating of scenes, products or VR applications VRML 2.0 enables represent static and animated objects too. It enables connections with sound, films, and pictures. Basic elements of VRML 2.0 usually correspond with used 3DAPI (Open GL, Direct 3D) [5].

Computer system ROANS is a software package on PC bases created for 3D simulation and programming of automated workplaces, robots and other peripheral devices. ROANS offers all the needed tools for robots creating and simulation. After designing of workplace subsystems and their placing in space, is able to create control program for all workplaces, in which it is working in multitasking mode. For minimalization of mistakes in program and for simple programming is added program editor [6].

ROANS, with help of integrated postprocessor program, generates control code for specific robot language. PC hardware enables ROANS to communicate straightly with robot (reading of joint coordinates from encoder of robot, translating of code from postprocessor into robot controller). The sample of automated workplace with robots created in ROANS and displayed in shade regime is on Figure 3.

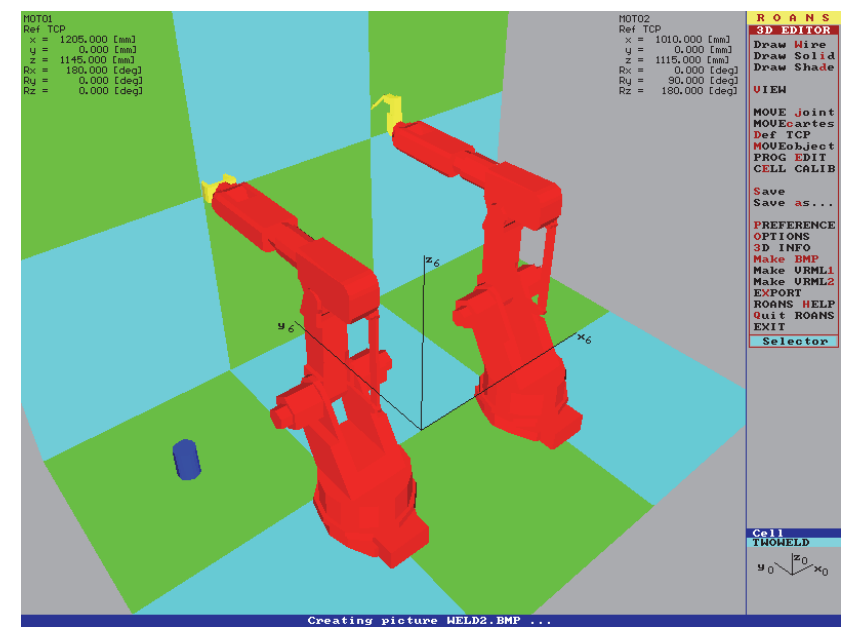

Figure 3 - Robot workplace in software ROANS

Before initiation of VRML implementation into system, ROANS needs to identify difference between structures in ROANS system and in VRML. This difference mainly comes from used program languages. ROANS was created in program language PASCAL. When the data are written into the file, they are indexed with rising value starting from number 1 . 
VRML language was created in $\mathrm{C}++$ language and data writing to file uses abilities of this language. Data are indexed with rising value starting from number 0 .

Differences in describing of points in ROANS system and VRML are in points indexing and in

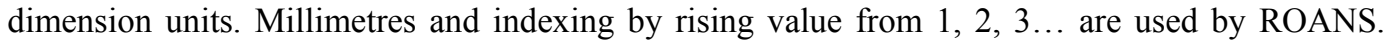
Meters and indexing by rising value from $0,1,2 \ldots$ are used by VRML.

Differences in line defining in system ROANS and VRML are in colour indexing and indexing of points which are needed to line defining. Line colours have their own identification number in ROANS system. Identification number of a colour depends on the order of colour defining in knots, which give a colour.

Differences in surface defining in system ROANS and VRML are in points indexing and in order of points, which describes creating of surface. Every surface has 2 sides. Feature in which surface is drawn in one or other side of object depends on order of point defining. ROANS system uses opposite principle for the point defining like VRML. That is why the program for VRML creating needs to write this indexing in opposite order like in ROANS. Adjustment of menu in ROANS is obvious from Figure 4 and Figure 5.

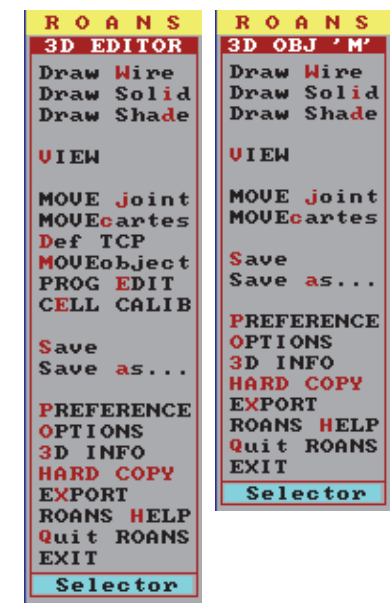

Figure 4 - Original menu

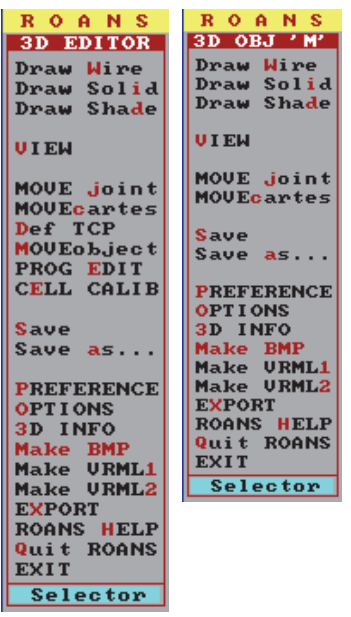

Figure 5 - Adjustment menu

The program for exporting ROANS data to VRML language is solved as part of ROANS system. In this case there are some changes in ROANS menu. The changes are: 3D Editor for Object structure, 3D Editor for Cell Structures, 3D Anim for Cell Structures.

Created program works with data, which are saved in memory of computer. This is the reason why displaying of workplace is not needed for exporting into VRML.

By activating of item MAKE VRML1 (stand with cursor on this item and than press ENTER, or right click of mouse, or pressing of hot key "1") activity of program is initialised. After this step setting the name of the file in which the result of export will be saved is needed. It is needed to enter the name without extension, which will be automatically added. After file creating, export of data starts. First header and preparatory knots (Info, BackgroundColor, ShapeHints, Material Binding, and Material) are exported. After this data of points (Coordinate3) are exported and depending on displaying regime data of lines (IndexedLineSet) and surfaces (IndexedFaceSet) are also exported. After ending of export exported file is closed and it is possible to work in ROANS system like before. 
Activity of making VRML 2.0 is similar like in VRML 1.0. It is initialised from menu by activating MAKE VRML2 item (stand with cursor on this item and than press ENTER, or right click of mouse, or pressing hot key "2"). After this procedure setting of the file name without extension WRL follows. After file has been created, export of data starts. First header and preparatory knots (WorldInfo and Background) are exported. After this, all data in dependence of displaying regime are exporting. Then, the export of lines (Shape - for lines) and surfaces (Shape for surfaces). In no visible shapes regime is process of points writing arranged. This is made in the case that some points are written twice and than they are marked with name "pts". When points and surfaces are defined they are extended by name ("pts"), which were defined in lines. After ending of export the exported file is closed and it is possible to work in ROANS system like before. On the Figure 6 displaying of automated workplace in VRML environment can be seen.

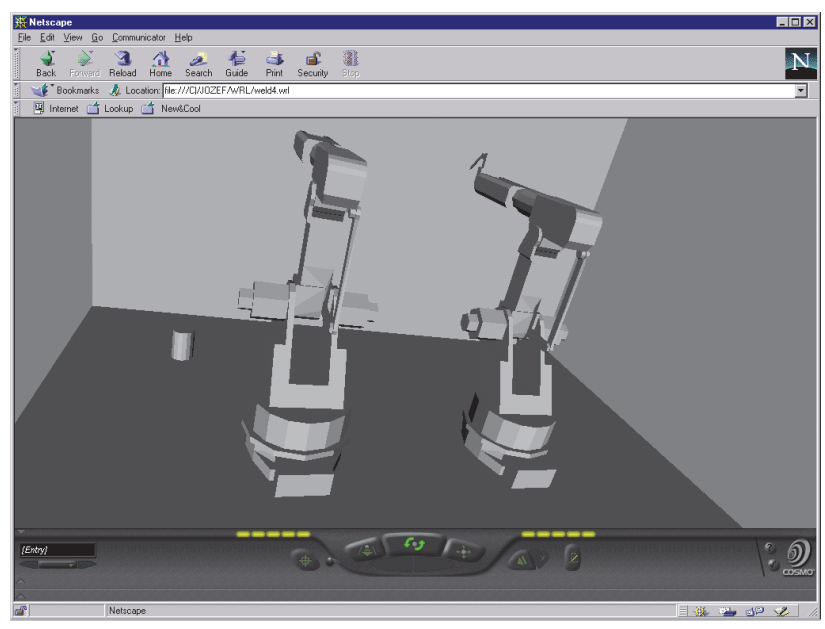

Figure 6 - Automated workplace in Netscape Environment

Virtual engineering is currently approached in various ways. Because virtual engineering is an emerging technology, its terminology and definition are not completely established. In manufacturing, the major component of virtual engineering is virtual manufacturing. Virtual manufacturing is defined as an integrated, synthetic manufacturing environment exercised to enhance all levels of decision and control. It can be classified as design-centred, productioncentred, and control-centred. Design-centred virtual manufacturing is a simulation environment for designing and evaluating the manufacturability of a product. Production-centred virtual manufacturing is a simulation environment for generating process plans and production plans. Control-centred virtual manufacturing is a simulation environment for shop floor production activities.

The most advanced current form of the Computer Aided Manufacturing is Virtual Manufacturing (VM) based on Virtual Reality (VR). VR representation techniques are widely used which means that they develop rapidly. In product manufacturing techniques and organization, virtual reality has become the basis of virtual manufacturing aimed at meeting the expectations of the users/buyers of products, also as to their low cost and lead time. Virtual manufacturing includes the fast improvement of manufacturing processes without drawing on the machines' operating time fund. It is said that Virtual Manufacturing is the use of a desktop virtual reality system for the computeraided design of components and processes for manufacture [2]. It is unquestionable that virtual 
manufacturing aids real manufacturing processes and systems and it is perfected as the information technologies, the manufacturing systems and the business demands development. In this context, Virtual Manufacturing should be recognized as an advanced information structure of Real Manufacturing Systems, which integrates the available information tools and the virtual environment immersiveness to achieve business-manufacturing goals.

\section{CONCLUSION}

After implementation of VRML maker into the ROANS system it is possible to represent all 3D automated workplaces with robot created in ROANS system by VRML browser, and it is not needed to have a license for ROANS. This enables companies, which use ROANS system, to communicate better without personal contact even if they are thousand kilometres apart. This could save financial resources and expressively decreases time of workplace designing expressively. VRML maker is integrated part of ROANS and does not increase hardware or even software requirements on system. It is needed to be enable work in ROANS system when making of VRML is wanted, because created data depend on displaying mode, which is set in menu Options. It is not needed to know how VRML works. Exploring of created scenes is enabled by individual programs (VRML browsers) or by additional programs for existing www browsers Netscape Navigator, Microsoft Internet Explorer (so called "plug in"). Introduced browsers and additional software can be obtained on Internet from web pages of these companies. Hardware and software requirements for scene exploring depend on used software.

\section{ACKNOWLEDGMENTS}

Ministry of Education, Science, Research and Sport of SR supported this work, contract VEGA No. 1/0036/09, KEGA No. 047-004TUKE-4/2010 and ITMS project 26220220125.

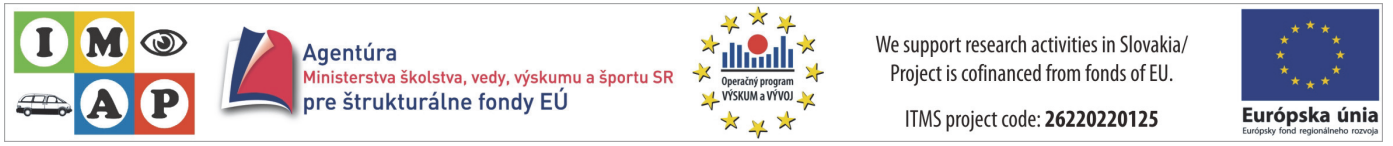

\section{REFERENCES}

[1] Lederer G.: Virtual Manufacturing - Manufacturers Challenge of the 1990s. CIME - Computer Integrated Manufacture and Engineering. No. 2, 1996, pp 44-46.

[2] Marcinčin J.N.: Application of the Virtual Reality Modeling Language for Design of Automated Workplaces. In: Proceedings of World Academy of Science, Engineering and Technology. Vol. 25, Venice (Italy), 2007, pp 160-163, ISSN 1307-6884.

[3] Jedrzejewski J., Kwasny W.: Remarks on state-of-the-art Virtual Manufacturing. In: Virtual Manufacturing. Wroclaw University of Technology, Wroclaw, 2001, pp 5-14. 
[4] Marcinčin J.N., Brazda P.: Virtual Reality as Workcell Design Verification Tool. In: Proceedings of the $12^{\text {th }}$ International Conference Trends in the Development of Machinery and Associated Technology TMT 2008. Istanbul (Turkey), 2008, pp 681-684, ISBN 978-9958-61741-6.

[5] Marcinčin J.N., Doliak M.: Computer Aided Robot Control as Subsystem of System CIM. In: Proceedings 8th International Workshop on Robotics in Alpe-Adria-Danube Region. Technische Universität München, München, 1999, pp 266-271, ISBN 3-00-004482-5.

[6] Marcinčin J.N.: Application of the Virtual Reality Modeling Language in Automated Technological Workplaces Design. Engineering Review, Vol. 27, No. 1, Faculty of Engineering University of Rijeka, 2007, pp 1-6, ISSN 1330-9587.

[7] Banerjee P., Zetu, D.: Virtual Manufacturing. John Wiley and Sons, New York, 320.

[8] Marcincin J.N.: Computer Aided Manufacturing and Virtual Manufacturing - History and Present Time. Informatyka, organizacja i zarzadzanie. Vol. 3, No. 13, ATH Bielsko-Biala, 2004, pp 199-204.

[9] Ong S. K., Nee A.Y.C.: Virtual and Augmented Reality Applications in Manufacturing. Springer-Verlag London, 387. 


\title{
PRIMENA VIRTUELNE REALNOSTI U PROIZVODNJI
}

\author{
Jozef Novak-Marcincin \\ Faculty of Manufacturing Technologies with a seat in Presov \\ Technical University of Kosice \\ Bayerova 1, 08001 Presov, Slovačka
}

\begin{abstract}
REZIME
Virtuelna realnost (VR) je postala veoma značajna u nauci i inženjerstvu. Primena VR obuhvata širok spektar industrijske problematike, od dizajna proizvoda $i$ analize, izrade prototipa $i$ proizvodnje. Dizajniranje $i$ proizvodnja proizvoda može biti ocenjivana $i$ unapređivana $u$ virtuelnom svetu pre nego što se prototip uopšte napravi, što dovodi do velikih ušteda. Virtuelna proizvodnja je upotreba kompjuterskih modela i simulacija proizvodnih procesa kako bi se unapredio proizvod i sam proces proizvodnje.

U ovom radu prikazana je primena VRML programskog jezika u virtuelnoj realnosti. ROANS je programski paket koji služi za $3 D$ simulaciju i programiranje različitih procesa automatizacije. ROANS obuhvata sve potrebne alate za simulaciju i programiranje robota. Implementacija VRML markera u ROANS sistem omogućava da se $3 D$ prezentacija svih automatskih radnih stanica $i$ robota prebaci u VRML pregledač, pa prema tome nije potrebno imati licencu za ROANS. Ovo omogućava kompanijama da lakśe komuniciraju između svojih filijala koje su hiljadama kilometara udaljene. Integracija VRML u ROAMS ne zahteva dodatno poboljšanje hardvera ili softvera.
\end{abstract}

Ključne reči: Virtuelna realnost, primena virtuelne realnosti, virtuelna proizvodnja 